\title{
Involvement of Wound-associated Factors in Rat Brain Astrocyte Migratory Response to Axonal Injury: In Vitro Simulation
}

\author{
A. Faber-Elman, ${ }^{\star}$ A. Solomon, ${ }^{\ddagger}$ J. A. Abraham, ${ }^{\S}$ M. Marikovsky, ${ }^{\mathbb{q}}$ and M. Schwartz ${ }^{\star}$ \\ *Department of Neurobiology and "Department of Cell Biology, The Weizmann Institute of Science, 76100 Rehovot, Israel; \\ ${ }^{\ddagger}$ Goldschleger Eye Research Institute, Sacler School of Medicine, Tel Aviv University, Sheba Medical Center, Tel Hashomer, Israel; \\ and ${ }^{\S}$ Scios Nova, Inc., Mountain View, California 94043
}

\begin{abstract}
The poor ability of mammalian central nervous system (CNS) axons to regenerate has been attributed, in part, to astrocyte behavior after axonal injury. This behavior is manifested by the limited ability of astrocytes to migrate and thus repopulate the injury site. Here, the migratory behavior of astrocytes in response to injury of CNS axons in vivo was simulated in vitro using a scratch-wounded astrocytic monolayer and soluble substances derived from injured rat optic nerves. The soluble substances, applied to the scratch-wounded astrocytes, blocked their migration whereas some known wound-associated factors such as transforming growth factor- $\beta_{1}$ (TGF- $\left.\beta_{1}\right)$, basic fibroblast growth factor (bFGF), epidermal growth factor (EGF), transforming growth factor- $\alpha$ (TGF- $\alpha)$, and heparin-binding epidermal growth factor in combination with insulin-like growth factor-1 (HB-EGF + IGF-1) stimulated intensive migration with consequent closure of the wound. Migration was not dominated by proliferating cells. Both bFGF and HB-EGF + IGF-1, but not TGF- $\beta 1$, could overcome the blocking effect of the optic nerve-derived substances on astrocyte migration. The induced migration appeared to involve proteoglycans. It is suggestive that appropriate choice of growth factors at the appropriate postinjury period may compensate for the endogenous deficiency in glial supportive factors and/or presence of glial inhibitory factors in the CNS. (J. Clin. Invest. 1996. 97:162-171.) Key words: astrocytes • growth factors $\bullet$ nervous system • wound healing • inflammation
\end{abstract}

\section{Introduction}

Axons of the central nervous system $(\mathrm{CNS})^{1}$ of mammals do not normally regenerate after injury, unlike those of phylogenetically lower vertebrate, such as fish and amphibians, or the peripheral nerves of mammals (for reviews see 1-3). Because

M. Marikovsky and M. Schwartz contributed equally to this manuscript.

Address correspondence to M. Schwartz, Department of Neurobiology, The Weizmann Institute of Science, 76100 Rehovot, Israel, Phone: 8.34.2467; FAX: 8.34.4131; E-mail: bnschwar@weizmann. weizmann.ac.il

Received for publication 5 July 1995 and accepted in revised form 8 September 1995.

J. Clin. Invest.

(C) The American Society for Clinical Investigation, Inc.

0021-9738/96/01/0162/10 \$2.00

Volume 97, Number 1, January 1996, 162-171 injured mammalian CNS axons can, under certain conditions, grow for considerable distances (for reviews see 1-3), it is generally believed today that the ability or inability of nerves to regenerate their injured axons depends on the cellular milieu surrounding the axons and its response to axonal injury.

Among the components of the cellular milieu are oligodendrocytes, astrocytes, resident microglia, and invading macrophages. Several studies have demonstrated the involvement of regeneration-related cross-talk between the immune and the nervous system. This cross-talk is apparently deficient in the CNS due to impairment of macrophage invasion (4; for reviews see 1-3). This impairment has been recently shown to be due to a CNS-resident macrophage inhibitory factor (5). In addition, the invading macrophages might be receiving an inappropriate stimulus for production of needed factors.

Proper stimulation of macrophages might be related, for example to the ability of the macrophages to produce the appropriate cytokines and growth factors needed to stimulate astrocytes for being conducive to axonal growth. Growth factors secreted by inflammatory cells might activate or inhibit some of the activities necessary for regeneration (6), such as protease activity (7), expression of specific extracellular matrix (ECM) components, cell migration or cell proliferation.

Astrocytes have been viewed as the cells which, following injury, form a scar that either acts as a mechanical barrier for growth or as a barrier due to a deficiency in growth supportive elements and/or presence of growth inhibitory elements (for reviews see $1-3$ ).

In fact, in response to axonal injury in the CNS astrocytes display conflicting effects (1-3). Thus for example, in both regenerating (fish) and nonregenerating (rat) central nervous systems, crush injury of optic nerve is followed by the disappearance of astrocytes from the site of injury. In fish, the injury site is subsequently repopulated by astrocytes, in temporal and spatial correlation with axonal growth across it (8-10). In the rat, the slow repopulation of the injury site by astrocytes is in apparent correlation with the failure of the regrowing injured axons to traverse it and may signify the astrocyte failure to express growth supportive elements. Although it is not yet known which comes first, axonal growth or astrocyte repopulation, it appears that the two phenomena are interdependent. Understanding why mammalian astrocytes fail to repopulate the site of injury and/or finding ways to overcome this failure will contribute significantly to the achievement of regeneration.

1. Abbreviations used in this paper: $\mathrm{bFGF}$, basic fibroblast growth factor; CNS, central nervous system; CSPG, chondroitin sulfate proteoglycan; DAPI, 4,6-dianidino-2-phenylindole; ECM, extracellular matrix; GFAP, glial fibrillary acidic protein; HB-EGF, heparin binding epidermal growth factor; HSPG, heparan sulfate proteoglycan. 
The ability of cells to migrate in general, and in particular in the case of astrocyte migration across the site of the injury, reflects their intrinsic properties as well as their cross-talk with the extracellular milieu of the nerve, including components associated with the local inflammatory reaction. Among these are growth factors, such as epidermal growth factor (EGF), heparin-binding EGF (HB-EGF), transforming growth factor- $\alpha$ (TGF- $\alpha$ ), transforming growth factor- $\beta_{1}\left(\right.$ TGF- $\left.\beta_{1}\right)$, insulin-like growth factor-1 (IGF-1), and basic fibroblast growth factor (bFGF), in tissue repair and wound healing (11-15). Some of these factors are angiogenic (16), some bind to ECM components (17-21), and some affect cell migration in various model systems in vitro (22-27). Likely candidates of such components are those which have been shown to be involved in tissue repair and wound healing.

In this study we examined the effects of various inflammation-associated factors on the migration of astrocytes, using an in vitro model to follow the astrocytic repopulation of a scratch wound inflicted on a monolayer of cultured astrocytes. Our experimental paradigm was similar to the one recently used to follow gliosis in response to in vitro injury (28), except that we used a defined medium (see Methods) rather than serum. This minimized cell proliferation throughout the follow-up period, and enabled us to achieve a well-defined and well-controlled experimental conditions.

We first examined whether the postinjury behavior of astrocytes in vivo could be simulated in vitro by the application of soluble substances derived from injured CNS (optic nerve) axons. We then applied various known wound-associated growth factors in the presence or absence of these soluble substances, and examined their effects on astrocyte migration and wound closure. Possible interrelationships between growth factors with respect to astrocyte migration were also examined. The results showed that the blockage of astrocyte migration in response to soluble substances originating from crushinjured optic nerves in vitro, is reminiscent to the astrocyte behavior in vivo in response to axonal injury. In contrast, bFGF, TGF- $\beta_{1}$ and factors of the EGF family (29-32), namely, EGF and TGF- $\alpha$ as well as HB-EGF in combination with IGF-1 (HB-EGF + IGF-1), were all capable of stimulating astrocyte migration. The observed wound repopulation appeared to involve proteoglycans. HB-EGF + IGF-1 and bFGF, but not TGF- $\beta_{1}$, could reverse the blocking of astrocyte migration caused by the optic nerve-derived substances.

\section{Methods}

Growth factors and cytokines. bFGF and interleukin-6 (IL-6) were purchased from Genzyme; TGF- $\beta_{1}$ from R\&D Systems and IL-2 from Peprotec. IGF-1, EGF and TGF- $\alpha$ were purchased from Collaborative Biomedical Products (Bedford, MA). Recombinant human HB-EGF consisted of residues 1-76, as predicted from the nucleotide sequence of the HB-EGF precursor's open reading frame, and was produced using an Escherichia coli expression system (33).

Preparation and wounding of astrocyte cultures. Astrocytes were prepared from the cerebral cortex of 2-d-old rats by a modification of the procedure of McCarthy and deVellis (34). After $11 \mathrm{~d}$, cells were trypsinized and plated in confluence on coverslips coated with polyD-lysine (PDL) $(20 \mu \mathrm{g} / \mathrm{ml})$ in 24 -well plates $(150,000$ cells $/ 300 \mu \mathrm{l} /$ well $)$ in growth medium. The growth medium was consisting of Dulbecco's modified Eagle's medium (DME), $2 \mathrm{mM}$ glutamine, $0.1 \mathrm{mg} / \mathrm{ml}$ transferrin, $0.1 \%$ free fatty acid bovine serum albumin (BSA), $0.1 \mu \mathrm{M} \mathrm{pu}-$ trescine, $0.45 \mu \mathrm{M}$ L-thyroxine and $0.224 \mu \mathrm{M}$ sodium selenite. After

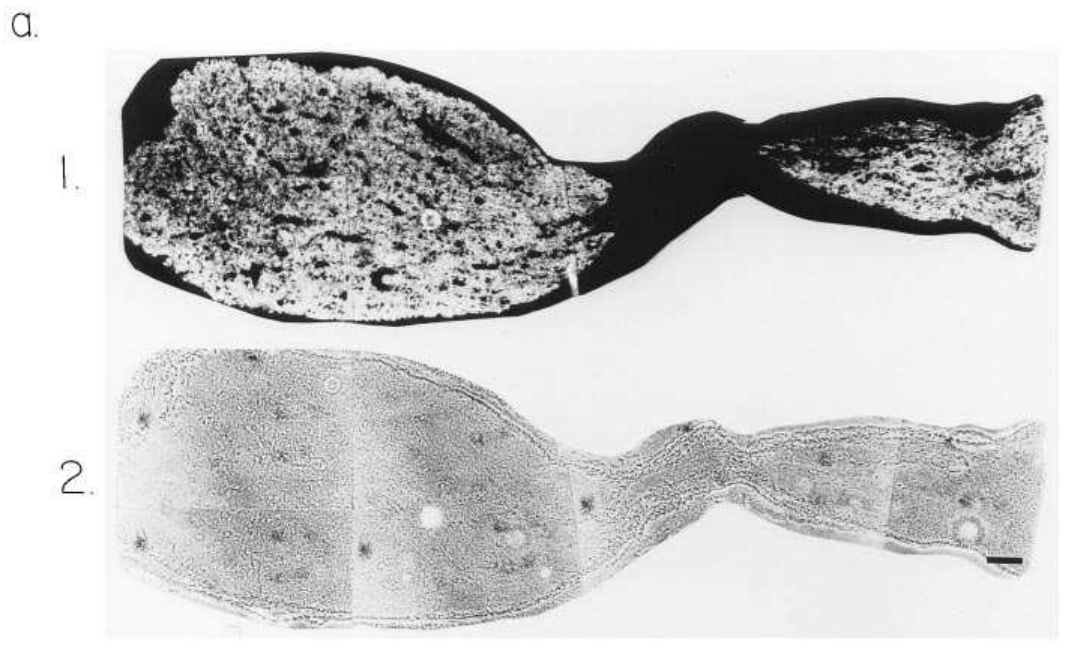

b.

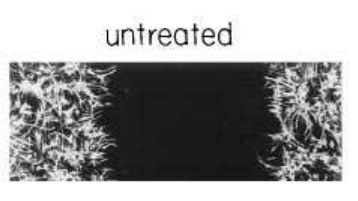

day 4

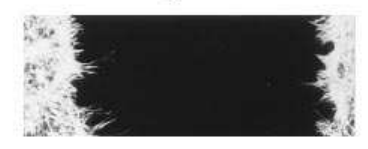

day 1

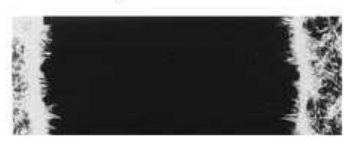

day 6

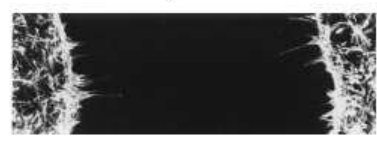

day 2

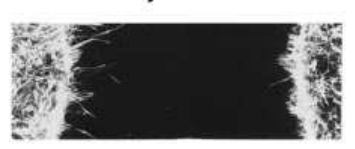

day 7

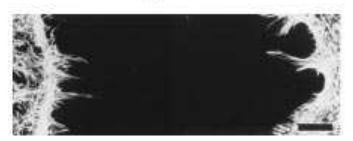

Figure 1. Comparison between wounded astrocytes in vivo and in vitro. (a) Longitudinal section of an adult rat optic nerve that was crush-injured $7 \mathrm{wk}$ before excision. Bar, $100 \mu \mathrm{m}$. (1) GFAP staining. (2) Phase contrast. The injured tissue was processed and stained with anti GFAP antibodies as described previously (8-10). (b) Scratch-wounded astrocytes were treated for $3 \mathrm{~d}$ with soluble substances $(25 \mu \mathrm{l})$ originating from the crush-injured nerves, then fixed and immunostained for GFAP. The soluble substances were obtained from injured nerves that were excised 1,3,5,6, and $7 \mathrm{~d}$ after injury. Representative results of one out of three experiments, performed in triplicates, are presented. Bar, $50 \mu \mathrm{m}$. Note the absence of GFAP staining at the injury site in all cases, indicating the absence of astrocytes. 
$24 \mathrm{~h}$ the medium was discarded and the monolayer was scratched with a sterile plastic pipette tip. The cells were washed three times with DME, and $300 \mu \mathrm{l}$ of growth medium were added. Cytokine or growth factor was added, and after $3 \mathrm{~d}$ of incubation $\left(37^{\circ} \mathrm{C}, 5 \% \mathrm{CO}_{2}\right)$, the cells were fixed and immunostained.

Injury of rat optic nerves, and preparation of nerve tissue for migration assay. Nerves were subjected to crush injury and animals were sacrificed at the indicated times after injury. The nerves were cleaned off their envelopes, transferred to an Eppendorf tube containing astrocyte growth medium $(50 \mu \mathrm{l}$ per nerve), pulverized with a pipette tip, incubated for $1 \mathrm{~h}$ at $4^{\circ} \mathrm{C}$, and frozen at $-70^{\circ} \mathrm{C}$. After thawing, tubes were centrifuged for $15 \mathrm{~min}$ in a microfuge and the supernatants collected. Each well of astrocytes in the migration assay was treated with $25 \mu \mathrm{l}$ of supernatant.

Immunofluorescence. For glial fibrillary acidic protein (GFAP) immunostaining, the cells were fixed with methanol $\left(10 \mathrm{~min}\right.$ at $\left.-20^{\circ} \mathrm{C}\right)$, immunostained $\left(30 \mathrm{~min}\right.$ at $\left.37^{\circ} \mathrm{C}\right)$ with a monoclonal anti-GFAP antibody (BioMakor, Israel) and diluted 1:100 in 1\% BSA/phosphatebuffered saline (PBS). For chondroitin sulfate proteoglycan (CSPG) immunostaining, the cells were fixed (20 $\mathrm{min}$ at room temperature) in $4 \%$ paraformaldehyde diluted in PBS, then incubated $(15 \mathrm{~min}$ at room temperature) with $0.15 \mathrm{M}$ glycine and permeabilized for $1 \mathrm{~min}$ with $0.05 \%$ Triton X-100 in PBS. Monoclonal anti-CSPG antibody (BioMakor, Israel), diluted 1:100 in 1\% BSA/PBS, was added ( $2 \mathrm{~h}$ at room temperature). For both immunostaining procedures the secondary antibody used was fluorescein isothiocyanate (FITC)-labeled goat anti-mouse IgG + IgM (Jackson ImmunoResearch Laboratories), diluted $1: 30$ in $1 \% \mathrm{BSA} / \mathrm{PBS}\left(30 \mathrm{~min}\right.$ at $\left.37^{\circ} \mathrm{C}\right)$. For 4,6 -dianidino-2-phenylindole (DAPI) staining, the cells were fixed with methanol $\left(10 \mathrm{~min}\right.$ at $\left.-20^{\circ} \mathrm{C}\right)$, washed in PBS, stained with DAPI $(500 \mathrm{ng} /$ $\mathrm{ml}) 15 \mathrm{~min}$ in room temperature, and washed again in PBS.

In situ $\left[{ }^{3} H\right]$ thymidine incorporation by the wounded astrocyte culture. A monolayer of astrocytes was wounded by scratching, as described above. $\left[{ }^{3} \mathrm{H}\right]$ thymidine (Rotem Industries, Israel) $(2 \mu \mathrm{Ci} / \mathrm{ml})$ was added to the cultures at the same time as the cytokines. After $3 \mathrm{~d}$ cells were washed with DME, fixed in methanol $\left(10 \mathrm{~min},-20^{\circ} \mathrm{C}\right)$, dehydrated in 70, 90 and $100 \%$ ethanol, exposed to Kodak emulsion for $3 \mathrm{~d}$ and stained with DAPI. The nuclei of cells repopulating the wound area were visualized by DAPI staining. Dark-field and phasecontrast microscopy were used to visualize the $\left[{ }^{3} \mathrm{H}\right]$-labeled nuclei of proliferating cells.

Heparinase and chlorate treatment of cells. For heparinase treatment, cells were plated on coverslips as described. After $24 \mathrm{~h}$ heparinase III (IBEX, Canada) $(0.01 \mathrm{U} / \mathrm{ml})$ was added, and after $1 \mathrm{~h}$ at $37^{\circ} \mathrm{C}$ a second aliquot of heparinase was added for $2 \mathrm{~h}$. The medium was then aspirated and the cells were scratched as described and treated with growth factors. Na-chlorate $(33 \mathrm{mM})$ was present throughout the experiment to block the sulfation of newly synthesized proteoglycans including heparan and chondroitin proteoglycans (35) during the 3-d period of the migration assay.
Assessment of repopulation of the wound area using image analysis. The extent of repopulation of the wound area by DAPIstained astrocytes was assessed by computerized image analysis using a Macintosh Quadra 950 with a Scion LV-3 frame grabber. The software used was the NIH-Image 1.51b Macintosh Quadra computer program (written by Wayne Rasband). A negative picture of the culture was captured and the captured frames were averaged to minimize noise). The number of cells per unit of scratched area was counted in an arbitrarily chosen sample area of $1 \mathrm{~mm}^{2}$. Experiments were performed in triplicate and the counts were averaged. The results were normalized relative to the number of cells counted in equal areas in the control untreated cultures and are presented as mean percentages.

\section{Results}

Simulation of the postinjury in vivo behavior of astrocytes by an in vitro model

Crush injury of rat optic nerve axons in vivo involves the axons and their associated glial cells. When excised and analyzed, the injury site is found to be devoid of astrocytes, as indicated by immunocytochemical staining with anti-GFAP antibodies (Fig. $1 a)$ and by transmission electron microscopical analysis as was previously shown by Blaugrund et al. $(8,9)$ and by Cohen et al. (10). To determine whether the relatively long-lasting absence of astrocytes at the injury site is related to the nature of the soluble substances associated with the injured nerve, we applied the optic nerve-derived soluble substances to a scratch wounded monolayer of astrocytes. As shown in Fig. 1, the response of astrocytes in the in vitro model simulates that observed in vivo. Thus in vitro wounded untreated astrocytes appear to avoid the site of injury and remain confined to its margins at least for the $5 \mathrm{~d}$ of the experiment. The addition of soluble substances derived from optic nerves caused blockage of astrocyte migration. The migration-blocking effects exerted by soluble substances derived from nerves excised at different time intervals after crush injury were similar (Fig. 1).

\section{Effects of wound-associated growth factors on wounded astrocytes in vitro}

Blockage and stimulation of astrocyte wound closure. In an attempt to find a factor(s) that might reverse the blocking effect of the physiological preparation (i.e., the optic nerve-derived soluble substances), we first examined the effect on wound closure of a number of known wound-associated factors, including IL-2, IL-6, IGF-1, EGF, TGF- $\alpha$, TGF- $\beta_{1}$, and bFGF. IL-2 (13-67 U/ml) and IL-6 (30-120 U/ml) had no effect on astro-
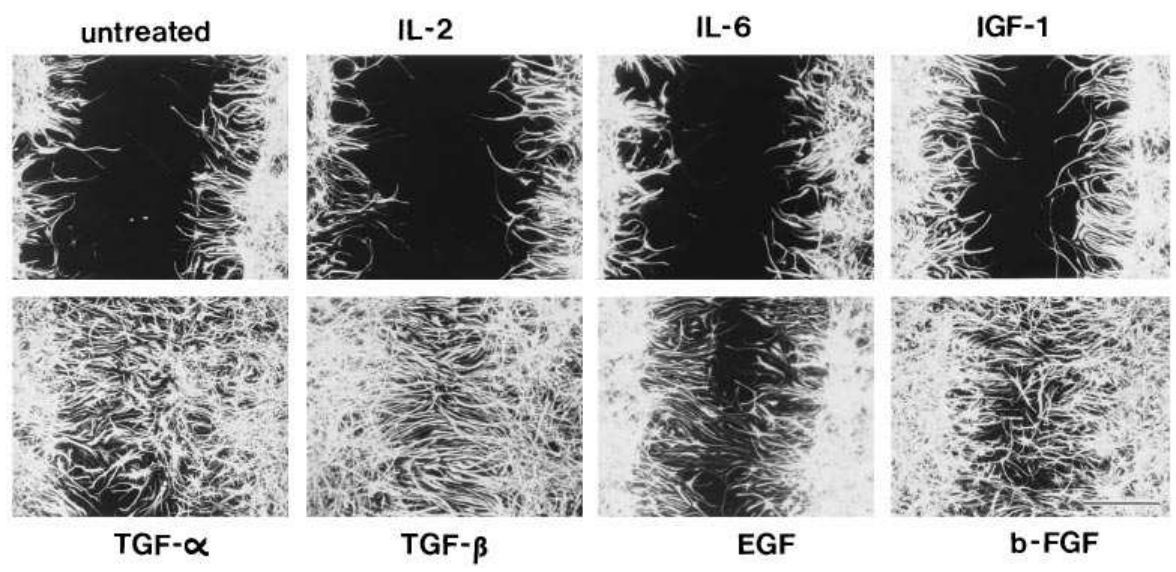

Figure 2. Effects of cytokines and growth factors on repopulation of the wound area by astrocytes in a scratch-wounded astrocytic monolayer. A monolayer of astrocytes was scratched and washed, as described in Methods. The indicated cytokines and growth factors were added at the following concentrations: bFGF, 20 $\mathrm{ng} / \mathrm{ml}$; TGF- $\beta_{1}, 35 \mathrm{ng} / \mathrm{ml}$; IGF-1, $100 \mathrm{ng} /$ $\mathrm{ml}$; IL-2, $54 \mathrm{U} / \mathrm{ml}$; IL-6, $60 \mathrm{U} / \mathrm{ml}$; TGF- $\alpha$ $90 \mathrm{ng} / \mathrm{ml}$; EGF $90 \mathrm{ng} / \mathrm{ml}$. After $3 \mathrm{~d}$, cultures were fixed and immunostained for GFAP. Representative results of one out of four experiments, performed in triplicates, are presented. Bar, $300 \mu \mathrm{m}$. 


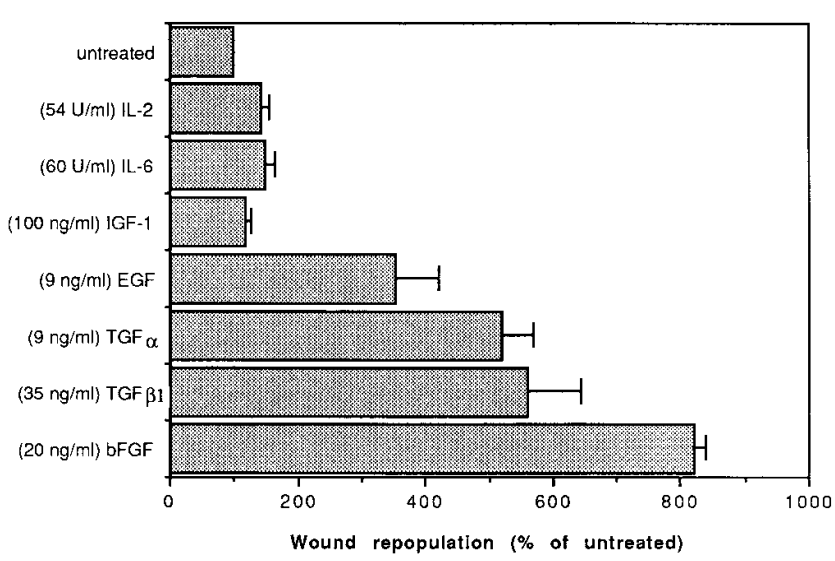

Figure 3. Quantitative analysis of wound closure by astrocytes in response to different treatments. A monolayer of astrocytes was wounded by scratching and was treated with growth factors or cytokines, as described in Methods. Micrographs of cultures stained for DAPI (see Methods) were analyzed using the NIH-Image 1.51b Macintosh Quadra computer program (written by Wayne Rasband). The number of cells per unit of scratched area was counted in an arbitrarily chosen sample area of $1 \mathrm{~mm}^{2}$. Three experiments were performed in triplicate and the counts were averaged. The results were normalized relative to the number of cells counted in equal areas in the control untreated cultures and are presented as mean percentage ( $\pm \mathrm{SD})$.

cyte migration relative to untreated cultures. Treatment with IGF-1 (at least $100 \mathrm{ng} / \mathrm{ml}$ ) increased migration slightly as compared to untreated controls (Fig. 2). However, treatment with EGF, TGF- $\alpha$, TGF- $\beta_{1}$, or bFGF, at the indicated concentra- tions, resulted in closure of the wound by astrocytes (Fig. 2; each treatment was performed using the optimal effective dose found by a dose-dependency curve). Closure was maximal after $3 \mathrm{~d}$ from the start of treatment. Nontreated cultures or cultures that were treated with noneffective factors, even at day 5 (the latest time point which was examined) after wounding did not show any closure. For the quantitative analysis of the wound closure we used DAPI staining rather than GFAP staining (Fig. 3) since GFAP staining did not allow distinction between a repopulation of the wound area by extension of fibers or migration of cell bodies which could be measured by nuclei staining (DAPI).

IGF-1 acts synergistically with factors of the EGF family on astrocyte migration. In view of the diversity of the effects of the tested factors we examined the possibility of relationships between them such as synergism, complementarity or competition. IGF-1 acts synergistically with EGF in inducing proliferation of newborn rat brain astrocytes (36). We therefore examined whether IGF-1 would also act in synergism with factors of the EGF family in promoting astrocytic repopulation of the wound in our model. Such synergism was observed when IGF-1 was applied in combination with EGF or TGF- $\alpha$ at concentrations lower than required for maximal migration. Synergism was also observed when IGF-1 was applied together with HB-EGF, which had no effect when applied alone (Fig. 4).

Repopulation of the wound area by astrocytes is not dominated by proliferating cells. Some of the above factors, e.g., EGF, IGF-1, and bFGF, are known to be mitogenic for astrocytes (36-41). It was therefore important to establish whether or not the observed repopulation was predominantly due to cell proliferation. We therefore assessed the frequency of

a

\section{b}
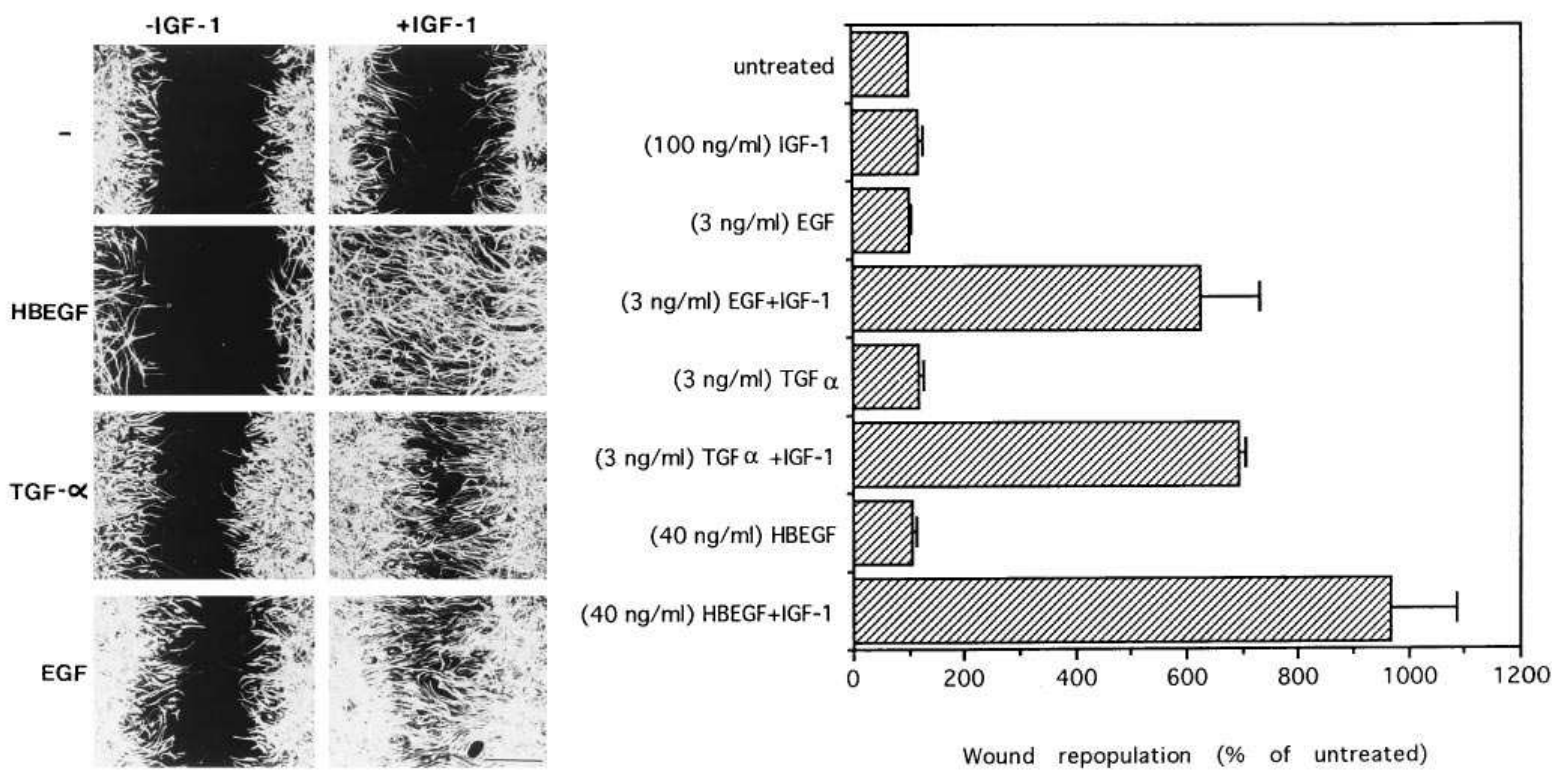

Figure 4. Synergistic augmentation of astrocyte migration following treatment with IGF-1 and EGF-related factors. A monolayer of astrocytes was wounded by scratching, as described in Methods, and treated with EGF ( $3 \mathrm{ng} / \mathrm{ml})$, HB-EGF (40 ng/ml), or TGF- $\alpha$ ( $3 \mathrm{ng} / \mathrm{ml})$ with or without IGF-1 (100 ng/ml). (a) Cells were fixed and immunostained for GFAP. Bar, $300 \mu \mathrm{m}$. (b) Quantitative analysis of wound closure by DAPIstained astrocytes in response to the above treatments. The number of cells per unit of scratched area was counted in an arbitrarily chosen sample area of $1 \mathrm{~mm}^{2}$. Three experiments were performed in triplicate and the counts were averaged. The results were normalized relative to the number of cells counted in equal areas in the control untreated cultures and are presented as mean percentage $( \pm S D)$. 

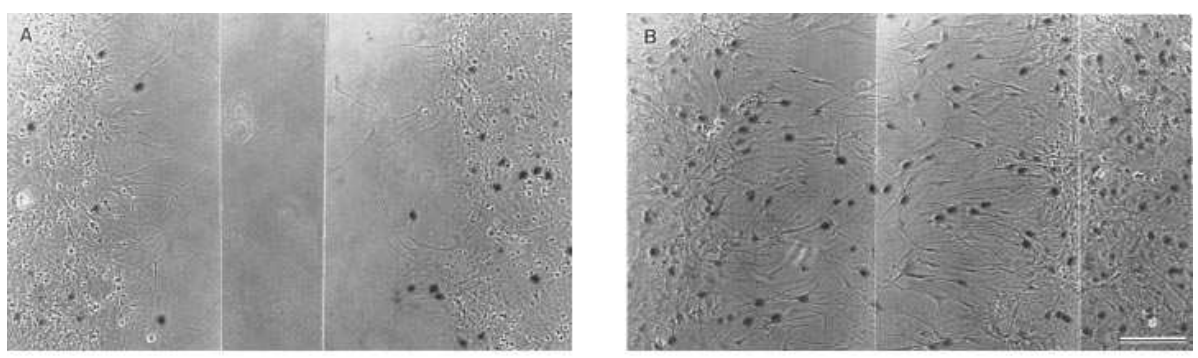

Figure 5. Incorporation of $\left[{ }^{3} \mathrm{H}\right]$ thymidine into astrocytes treated with HBEGF + IGF-1. A monolayer of astrocytes was wounded by scratching, as described in Methods, and treated with HB-EGF $(40 \mathrm{ng} / \mathrm{ml})$ in combination with IGF-1 (100 ng/ml). $\left[{ }^{3} \mathrm{H}\right]$ Thymidine was added at the same time as the growth factors. The number of nuclei labeled with $\left[{ }^{3} \mathrm{H}\right]$ thymidine was calculated as a percentage of DAPIstained nuclei (visualized by UV microscopy as bright dots). Similar results were obtained with all of the migration-inducing cytokines. $(A)$ Untreated culture. Bar, $200 \mu \mathrm{m}$. (B) Culture treated with HB-EGF +

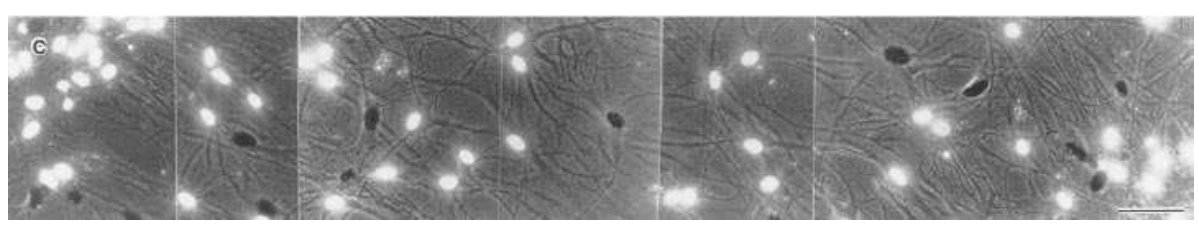
IGF-1. Bar, $200 \mu \mathrm{m}$. (C) Phase-contrast and UV micrographs of a culture treated with HB-EGF + IGF-1. Bar, $50 \mu \mathrm{m}$. Representative results of one out of five experiments, performed in triplicates, are presented.

$\left[{ }^{3} \mathrm{H}\right]$ thymidine-labeled cells among the repopulating cells in all the factors examined in this work. For example, in wounded cultures treated with HB-EGF + IGF-1, most of the repopulating cells were not labeled with $\left[{ }^{3} \mathrm{H}\right]$ thymidine (Fig. $5 \mathrm{~B}$ ). Double labeling of cells with $\left[{ }^{3} \mathrm{H}\right]$ thymidine (which labels nuclei of proliferating cells) and DAPI (which stains all cell nuclei) enabled us to determine the proportion of thymidinelabeled cells among the total number of cells repopulating the wound (Fig. $5 \mathrm{C}$ ). Quantitative analysis revealed that the percentage of labeled astrocytes repopulating the site of injury in treated cultures ranged between 21 and $31 \%$ (the mean for all treatments was $26.9 \pm 3.7 \%$ ) and was similar to that observed in control untreated cultures (mean $30.7 \%$ ). In addition, significant astrocytic repopulation of the wound was stimulated by TGF- $\beta_{1}$ (Figs. 3 and 6), which is not mitogenic for astrocytes $(42,43)$.

Involvement of proteoglycans in migration induced by wound-associated factors. Proteoglycans are known to be involved in cell migration by virtue of their effects on cell attachment to, and detachment from, the substratum (44-46). We therefore examined whether heparan sulfate proteoglycans (HSPG) and chondroitin sulfate proteoglycans (CSPG) are involved in the migratory behavior of astrocytes. Migration in response to stimulation by each of the wound-associated factors was measured in cultures that had been preincubated for $3 \mathrm{~h}$ with heparinase III. During the $3 \mathrm{~d}$ of the assay Na-chlorate was included in the media of all cultures pretreated with heparinase, in order to block sulfation of newly synthesized HSPG (35). Treatment with heparinase $+\mathrm{Na}$-chlorate markedly inhibited the stimulation of astrocyte migration both by the heparin-binding factors (HB-EGF, bFGF, and TGF- $\beta_{1}$; Fig. 7) and by factors that do not bind heparin (EGF, TGF- $\alpha$; Fig. 8). The inhibition was not a function of time as no migration was observed even $5 \mathrm{~d}$ after wounding and enzyme application. Since treatment with heparinase + Na-chlorate inhibited the migration normally induced by these factors, it seems that the presence of HSPGs is necessary for the migration process itself. This would be in line with the fact that all tested factors were affected by the heparinase treatment, regardless of whether they bind heparin (HB-EGF, TGF- $\beta_{1}$, and bFGF) or not (EGF, TGF- $\alpha$ ).

It should be noted that the use of Na-chlorate is expected to affect sulfation not only of HSPG but also of CSPG (35), and therefore, it might affect CSPG levels as well. However, when $\mathrm{Na}$-chlorate was added to wounded cultures treated with any of the migration-inducing factors, in the absence of heparinase no effect on astrocyte migration could be detected (data not shown). For a direct assessment of the possible involve-
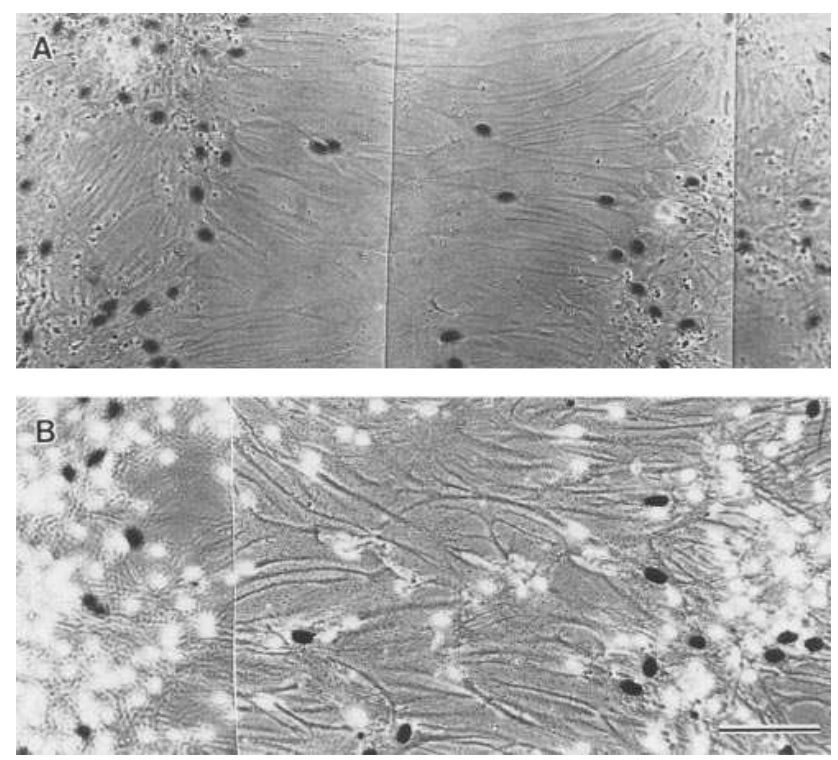

Figure 6. Incorporation of $\left[{ }^{3} \mathrm{H}\right]$ thymidine into astrocytes treated with TGF- $\beta_{1}$. A monolayer of astrocytes was wounded by scratching, as described in Methods, and treated with TGF- $\beta_{1}(35 \mathrm{ng} / \mathrm{ml})$. $\left[{ }^{3} \mathrm{H}\right]$ Thymidine $(2 \mu \mathrm{Ci} / \mathrm{ml})$ was added at the same time as TGF- $\beta_{1}$. Bright nuclei represent DAPI-stained nuclei and dark nuclei represent nuclei of proliferating astrocytes. $(A)$ Phase-contrast micrograph. (B) Combination of phase-contrast and ultraviolet (UV) micrographs. Representative results of one out of five experiments, performed in triplicates, are presented. Bar, $600 \mu \mathrm{m}$. 


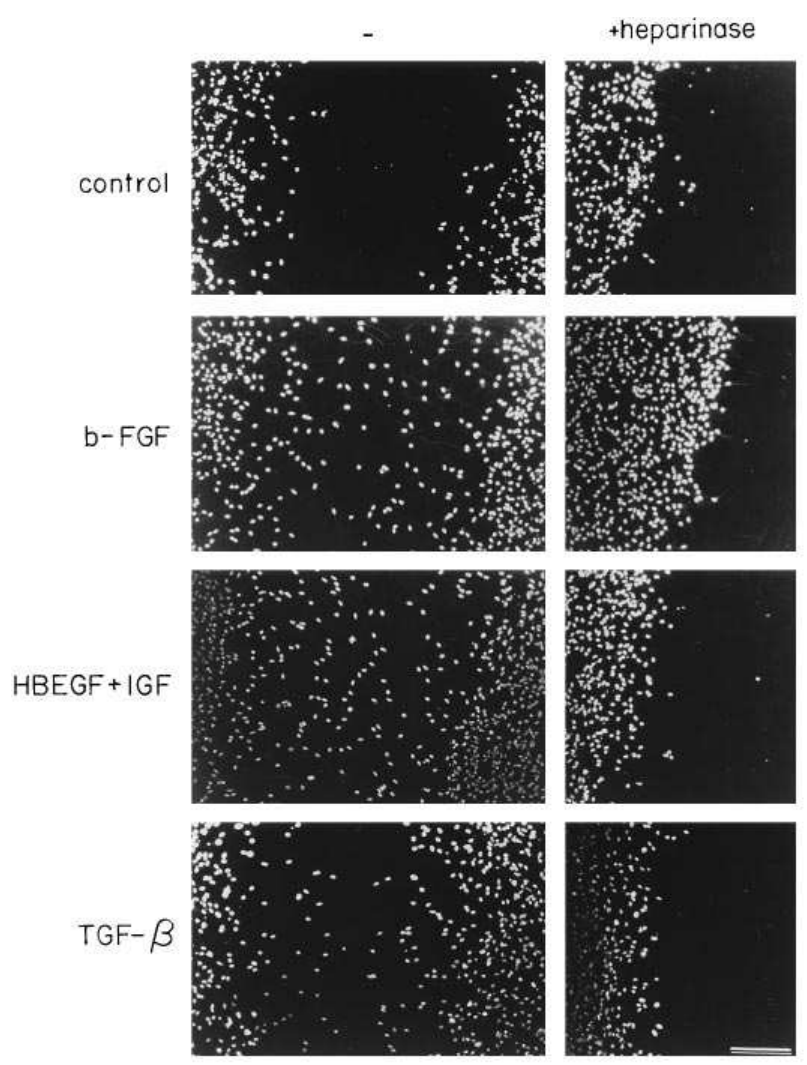

Figure 7. Effects of heparinase III and Na-chlorate on astrocyte migration induced by heparin-binding factors. A monolayer of astrocytes was pretreated with heparinase III, wounded by scratching as described in Methods, and treated with growth factors at the following concentrations: HB-EGF (40 ng/ml), IGF-1 (100 ng/ml), bFGF $(20 \mathrm{ng} / \mathrm{ml})$, and TGF- $\beta_{1}(35 \mathrm{ng} / \mathrm{ml})$. Na-chlorate $(33 \mathrm{mM})$ was present throughout the assay. After $3 \mathrm{~d}$, cells were fixed and stained for DAPI. Representative results of one out of four experiments, performed in triplicates, are presented. Bar, $200 \mu \mathrm{m}$.

ment of CSPG in the observed migration, we used an indirect immunohistochemistry which allowed comparison of CSPG expression in the various areas of the wounded monolayer. The identity of the CSPG-immunoreactive protein was confirmed by Western blot analysis (data not shown). Using these antibodies, expression of CSPG on the cell surface was found to be elevated after treatment with the maximal effective concentration of migration-promoting factors (Fig. 9).
Overcoming the blocking effect of the nerve-derived soluble substances on astrocyte migration

In view of the possible relevance of the blocking of the spontaneous migration of astrocytes by the optic nerve-derived soluble substances, as observed here in vitro (Fig. 1), to the astrocyte response to injury in vivo, we examined whether it could be reversed by any of the migration-promoting factors. Specifically, we examined heparin binding factors (e.g., bFGF, TGF$\beta_{1}$, or HB-EGF), known to be capable of creating effective local concentrations by association with the substratum. As shown in Fig. 10, the blockage was only slightly attenuated by treatment with HB-EGF or IGF-1 alone, but was completely reversed by HB-EGF + IGF-1 (Fig. 10). The blockage could also be reversed by treatment with bFGF, but not with TGF$\beta_{1}$, even though TGF- $\beta_{1}$ was applied in concentrations which were not toxic and which induced migration in our experimental model.

\section{Discussion}

The results of this study show that wound-related factors affect astrocyte migration in vitro in a way that may be relevant for modulation of the posttraumatic astrocyte behavior needed for regeneration of CNS nerves in vivo. There they are exposed to wound-related factors produced by invading macrophages as well as by resident cells $(42,47-51$, for review see 1). It is possible, however, that the absence of needed factors or their presence in inappropriate concentrations or along with inappropriate composition or the presence of inhibitory factor(s) might be a reason for the failure of in vivo migration of astrocytes. In the present study we provide an insight to this dilemma using a scratch-wounded monolayer of rat astrocytes and examined wound closure in response to various woundrelated factors.

The migration of astrocytes across the wound in our in vitro model was blocked by soluble substances associated with the injured optic nerve in vivo. Examination of identified wound associated factors revealed that some growth factors and cytokines did not confine cells to the margins of the wound, but allowed them to populate the wounded area. Thus, for example, repopulation of the site of injury by astrocytes was found to be stimulated by TGF- $\beta_{1}$ and bFGF, as well as by a combination of EGF, TGF- $\alpha$, or HB-EGF with IGF-1. Activity of HB-EGF in connection with the nervous system is described here for the first time. Synergism between IGF-1 and HB-EGF has been shown to enhance DNA synthesis in kera-
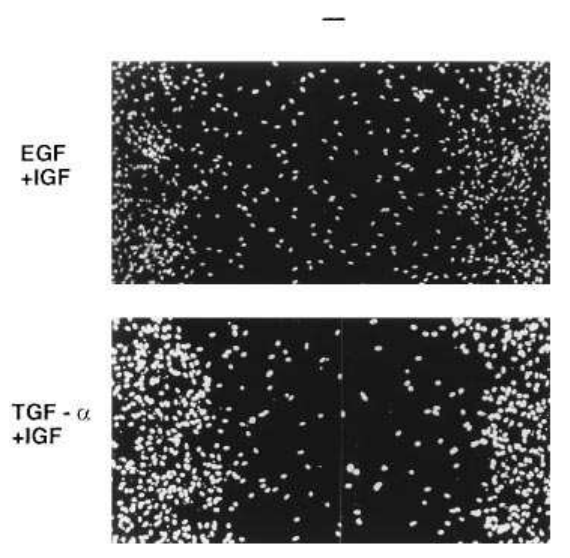

theparinase
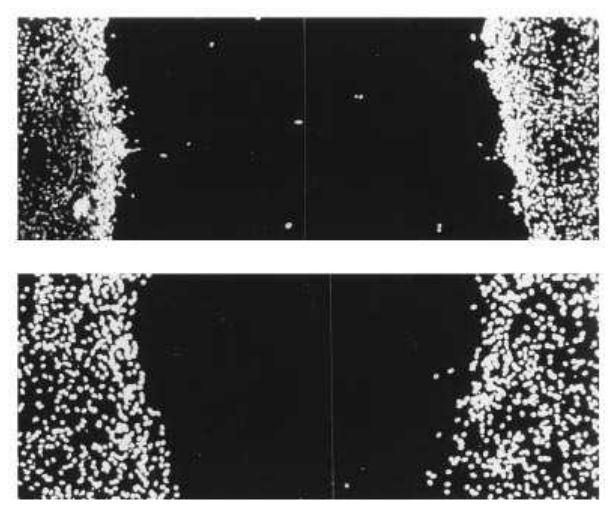

Figure 8. Effects of heparinase III and Na-chlorate on astrocyte migration induced by non-heparin-binding factors. A monolayer of astrocytes was pretreated with heparinase III, wounded by scratching as described in Methods, and treated with growth factors at the following concentrations: EGF (3 ng/ml), IGF-1 (100 $\mathrm{ng} / \mathrm{ml}), \mathrm{TGF}-\alpha(3 \mathrm{ng} / \mathrm{ml})$. Na-chlorate (33 $\mathrm{mM}$ ) was present throughout the assay. After $3 \mathrm{~d}$, cells were fixed and stained for DAPI. Representative results of one out of four experiments, performed in triplicates, are presented. Bar, $200 \mu \mathrm{m}$. 
untreated

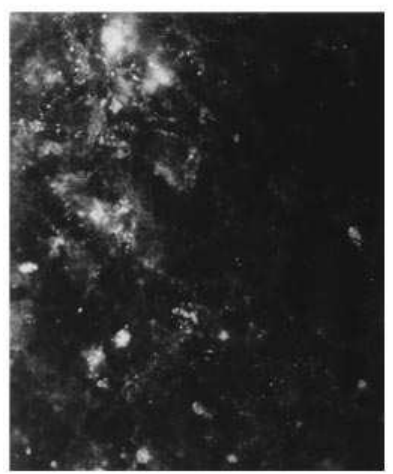

HBEGF+IGF
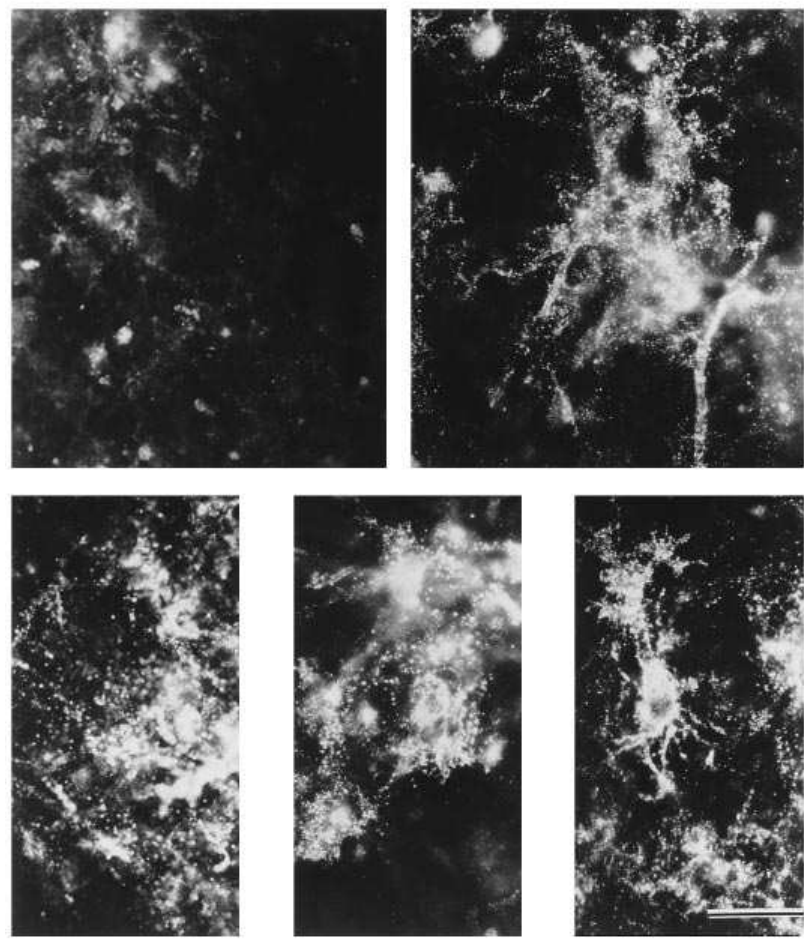

TGF $-\beta_{1}$

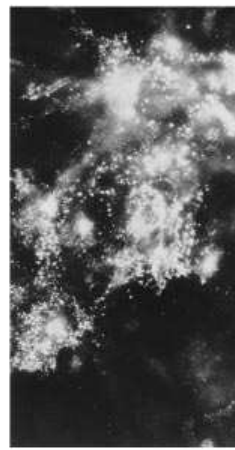

b-F GF

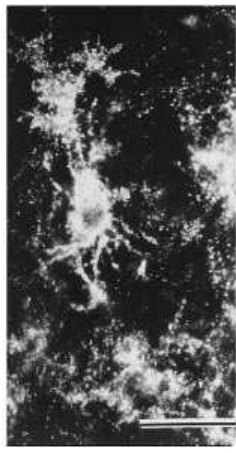

EGF+IGF

Figure 9. CSPG immunoreactivity in astrocytes. Astrocytes were wounded and treated with growth factors at the following concentrations: b-FGF, 20 ng/ml; EGF, 3 ng/ml; HB-EGF, 40 ng/ml; IGF-1 (IGF), $100 \mathrm{ng} / \mathrm{ml}$; TGF- $\beta_{1}, 35 \mathrm{ng} / \mathrm{ml}$. At the end of the follow-up period $(3 \mathrm{~d})$, cells were fixed and stained for CSPG immunoreactivity. Note the low levels of reactivity in control untreated cultures compared to the levels in cultures treated with TGF- $\beta_{1}$, bFGF and HB$\mathrm{EGF}+\mathrm{IGF}-1$. Representative results of one out of three experiments, performed in duplicates, are presented. Bar, $50 \mu \mathrm{m}$.

tinocytes (Marikovsky et al., manuscript submitted for publication). One of the mechanisms that might be responsible for such synergism is transmodulation of the EGF or the IGF-1 receptor, which was demonstrated in keratinocytes (52). It should be noted that IGF-1 in the present study was applied at the physiological concentrations found in other wounded systems, for example in skin injuries (53, Marikovsky et al., manuscript submitted for publication).

Our results appear to rule out the possibility that the observed effect of the examined growth factors on repopulation of the wounded area is due to proliferation of astrocytes. Thus, even factors known to affect astrocyte proliferation, such as bFGF $(38,43,54)$ and IGF-1 (41), seemed to increase the migratory ability of astrocytes independently of that effect, since only $\sim 30 \%$ of the cells were found to be synthesizing DNA. This is in agreement with the observations that in a similar model system, migration of IEC-6 cells was independent of DNA synthesis, and the cells first migrate and then divide (55). In addition, as was shown above, TGF- $\beta_{1}$, which is not mitogenic for astrocytes, caused their migration, although not necessarily via the same mechanism as that mediated by bFGF and/ or members of the EGF family.

O.N.
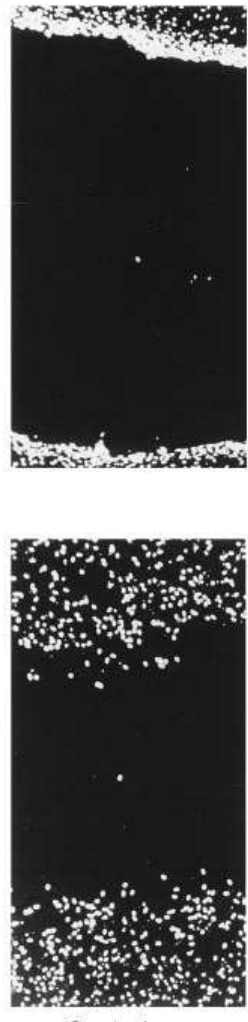

Control
O.N. + IGF
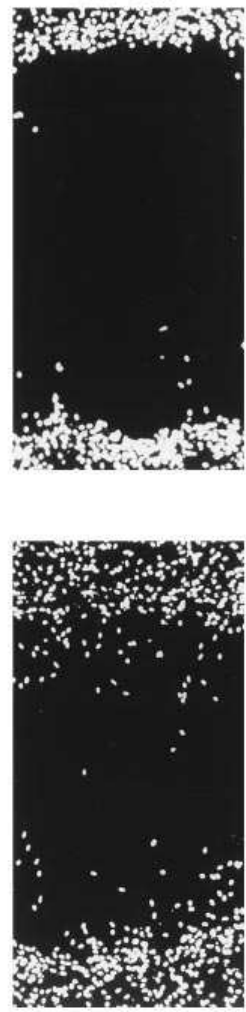

O.N. + HB-EGF
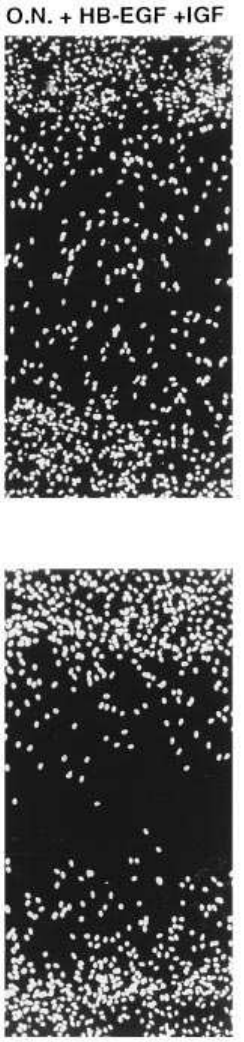

O.N. + bFGF
Figure 10. bFGF or HB-EGF + IGF-1 reverse the blocking of astrocyte migration caused by soluble substances originating from injured optic nerves and promote astrocyte migration in a scratch-wounded astrocytic monolayer. A monolayer of astrocytes was scratched and washed, as described in the Methods. Soluble substances $(25 \mu \mathrm{l})$ originating from injured optic nerves that were excised $3 \mathrm{~d}$ after crush injury were added with or without growth factors at the following concentrations: bFGF, 20 ng/ml; HB-EGF, 35 ng/ml; IGF-1, 100 ng/ml. After $3 \mathrm{~d}$ cultures were fixed and immunostained for GFAP. Representative results of one out of three experiments, performed in triplicates, are presented. Bar, $300 \mu \mathrm{m}$.

Some of the factors which stimulate astrocyte migration could also reverse the blockage imposed on it by the soluble substances associated with the in vivo response to injury. Among these factors are bFGF and HB-EGF + IGF-1. It is not yet clear whether the astrocyte migration induced by each of these factors involves the same or different mechanisms. It is possible that in some cases the growth factor does not induce wound repopulation directly, but causes the astrocytes to secrete a common mediator, which in turn may directly induce wound closure. Such an indirect mechanism might involve a growth factor-induced production of cell adhesion molecules (56), ECM receptors (integrins and nonintegrins) (57), ECM components (58), ECM components containing EGF-like domains, e.g., laminin (59), tenascin (60), or thrombospondin (61), or other growth factors (56). For example, TGF- $\beta_{1}$ increases the synthesis and cell surface expression of integrins by several cell types $(62,63)$, as well as the expression of cell-surface CSPG and dermatan sulfate proteoglycan $(64,65)$ and proteoglycan metabolism $(66,67)$. Moreover, CSPG levels have been correlated with detachment and migration of cells such as endothelial cells (44-46). However, our results, which 
show elevation of CSPG levels by the growth promoting factors do not allow a direct correlation between the induced migration and the observed increase of CSPG immunoreactivity since prevention of sulfation of the newly synthesized CSPG apparently did not block migration. Our results do suggest the possible involvement of HSPG, as treatment of the cells with heparinase before the addition of the factors blocked the induced migration, even when using factors that do not bind heparin (e.g., EGF and TGF- $\alpha$ ). However, the fact that heparinase blocked migration induced by several growth factors and even by non-heparin-binding factors suggests that HSPG is necessary not only for binding of the growth factor but also for the migration process itself.

As mentioned above, the migration induced by the various factors could be due to elevated secretion of migration-promoting factors produced by the astrocytes as a result of the treatments. The low level of such factors in untreated cells might thus explain their limited spontaneous migration. Thus, for example, astrocytes have been shown to secrete TGF- $\beta_{1}$ (68), IGF-1 $(69,70)$, bFGF (71), and to express HB-EGF transcripts (G. Raab and M. Klagsbrun, unpublished results).

It may be concluded from this study that the presence of specific wound associated factors might be necessary for astrocytes to migrate at a critical time after injury, and that their absence, or their presence in suboptimal amounts, even if temporary, might result in an astrocyte response which is not conducive to regeneration. The concentrations of individual growth factors and cytokines and the precise timing of their release may determine the final outcome of the inflammatory and regenerative processes associated with nerve wound healing. This may explain the observed blockage imposed by soluble substances derived from the optic nerve, which might contain nearly all the factors needed but be deficient in migrationinducing factor(s) or contain migration inhibitory factor(s), both of which may be compensated for by appropriate growth factor treatment. This is in line with recent evidence pointing to an important role for macrophages in modulating the nerve's ability to regenerate after injury. Injury to the sciatic nerve (a spontaneously regenerating system) is followed by its rapid invasion by large numbers of macrophages. In contrast, the number of macrophages entering the injured optic nerve (which does not regenerate spontaneously) is small (4). The limited invasion of the optic nerve may also signify an inappropriate activation of macrophage leading to an inappropriate repertoire of growth factors produced locally by the inflammatory cells (monocytes and macrophages) that invade the injured nerve and/or by the nerve-resident cells with which they interact. To compensate for the presumed deficiency of growth factor(s), or for the presumed presence of inhibitory factor(s) in the optic nerve, treatment of the injured nerve, within a critical time period after injury, by exogenous application of certain macrophage- or platelet-derived cytokines and growth factors, which were also shown to be present in wound during normal repair, such as TGF- $\beta(11,72)$, IGF-1 $(11,73,74)$, or HB-EGF $(15,32,75)$, might be beneficial for nerve regeneration.

When considering such treatment, one should also take into account the possible effects of the applied growth factors and cytokines on other cells of the nerve. For example, neuronal survival was found to be increased by IGF-1 (76-80, for review see 1$)$, TGF- $\beta_{1}(81)$ and bFGF (82-85, for review see $1)$. Accordingly, such factors might be promising candidates for therapeutic administration.
In selecting an appropriate in vivo growth factor treatment for injured nerves, with the object of increasing the postinjury migratory ability of astrocytes, one should also consider the stability and availability of the applied growth factor within its area of application. One possible way in which growth factors might become part of a stable complex is via their association with HSPG in the ECM or on the cell surface (81-86). Such an association might also effectively increase their local concentration, thereby enhancing their therapeutic potential. HBEGF, TGF- $\beta_{1}$, and bFGF all bind to HSPG on the cell surface $(21,24,87)$, and bFGF also binds to HSPG in the ECM (18). We therefore suggest that treatment of injured nerves with these growth factors might result in their binding to HSPG on the cell surface or in the ECM in the vicinity of the injury site, and thus might have a beneficial affect on the response of astrocytes to injury.

\section{Acknowledgments}

We thank Shirley Smith and Morgan Wain-Hirschberg for editorial assistance, and David L. Hirschberg for establishing the setup of the image analyses. Michal Schwartz is the incumbent of the Maurice and Ilse Katz Professorial Chair in Neuroimmunology.

This work was supported in part by the Alan T. Foundation of Nerve Paralysis, USA and Daniel Heumann Foundation for Spinal Cord Injury.

\section{References}

1. Lotan, M., and M. Schwartz. 1994. Cross talk between the immune system and the nervous system in response to injury: implications for regeneration. FASEB J. 8:1026-1033.

2. Sivron, T., and M. Schwartz. 1995. Glial cell types, lineages, and response to injury in rat and fish: implications for regeneration. Glia. 13:157-165.

3. Schwartz, M., T. Sivron, S. D. Eitan, L. Hirschberg, M. Lotan, and A. Faber-Elman. 1994. Cytokine and cytokine-related substances regulating glial cell response to injury of the central nervous system. In Progress in Brain Research. Vol. 103. F. J. Seil, editor. Elsevier Science B.U., Amsterdam.

4. Perry, V. H., M. C. Brown, and S. Gordon. 1987. The macrophage response to central and peripheral nerve injury. J. Exp. Med. 165:1218-1223.

5. Hirschberg, D. L., and M. Schwartz. 1995. Macrophage recruitment to the CNS is inhibited by a resident factor: a basis for an immune-brain barrier. $J$. Neuroimmunol. 61:89-96.

6. David, S., C. Bouchard, O. Tsatas, and N. Giftochristos. 1990. Macrophages can modify the nonpermissive nature of the adult mammalian central nervous system. Neuron. 5:463-469.

7. Faber-Elman, A., R. Miskin, and M. Schwartz. 1995. Components of the plasminogen activator system in astrocytes are modulated by tumor necrosis factor $\alpha(\mathrm{TNF}-\alpha)$ and interleukin $1 \beta(\mathrm{IL}-1 \beta)$ through similar signal transduction pathways. J. Neurochemistry. 65:1524-1535.

8. Blaugrund, E., R. Duvdevani, V. Lavie, A. Solomon, and M. Schwartz. 1992. Disappearance of astrocytes and invasion of macrophages following crush injury of adult rodent optic nerves: implications for regeneration. Exp. Neurol. 118:105-115.

9. Blaugrund, E., V. Lavie, I. Cohen, A. Solomon, D. J. Schreyer, and M. Schwartz. 1993. Axonal regeneration is associated with glial migration: comparison between the injured optic nerves of fish and rats. J. Comp. Neurol. 330: $105-112$.

10. Cohen, I., Y. Shani, and M. Schwartz. 1993. Cloning and characterization of fish glial fibrillary acidic protein: implications for optic nerve regeneration. J. Comp. Neurol. 334:431-443.

11. Rappolee, D. A., D. Mark, M. J. Banda, and Z. Werb. 1988. Wound macrophages express TGF- $\alpha$ and other growth factors in vivo: analysis by mRNA phenotyping. Science (Wash. DC). 241:708-712.

12. Lynch, S. E., R. B. Colvin, and H. N. Antoniandes. 1989. Growth factors in wound healing, single and synergistic effects on partial thickness porcine skin wounds. J. Clin. Invest. 84:640-646.

13. Roberts, A. B., and M. B. Sporn. 1990. Peptide growth factors and their receptors. Springer-Verlag, New York.

14. Whitby, D. J., and M. W. J. Ferguson. 1991. Immunohistochemical localization of growth factors in fetal wound healing. Dev. Biol. 147:207-215.

15. Marikovsky, M., K. Breuing, P.-Y. Liu, E. Eriksson, S. Higashiyama, P. Farber, J. A. Abraham, and M. Klagsbrun. 1993. Appearance of heparin-bind- 
ing EGF-like growth factor (HB-EGF) in wound fluid as a response to injury. Proc. Natl. Acad. Sci. USA. 90:3889-3893.

16. Folkman, J., and M. Klagsbrun. 1987. Angiogenic factors. Science (Wash. DC). 235:442-447.

17. Gospodarowicz, D., J. Cheng, G. M. Lin, A. Baird, and P. Bohlen. 1984. Isolation of brain fibroblasts growth factor by heparin-Sepharose affinity chromatography: identity with pituitary fibroblast growth factor. Proc. Natl. Acad. Sci. USA. 81:6963-6967.

18. Vlodavsky, I., J. Folkman, R. Sullivan, R. Friedman, R. Ishai-Michaeli, J. Sasse, and M. Klagsbrun. 1987. Endothelial cell-derived basic fibroblast growth factor: synthesis and deposition into subendothelial extracellular matrix. Proc. Natl. Acad. Sci. USA. 84:2292-2296.

19. Mooradian, D. L., R. C. Lucas, J. A. Weatherbee, and L. T. Furcht. 1989. Transforming growth factor- $\beta_{1}$ binds to immobilized fibronectin. J. Cell. Biochem. 41:189-200.

20. Paralkar, V. M., S. Vukicevic, and A. H. Reddi. 1991. Transforming growth factor- $\beta$ type 1 binds to collagen IV of basement membrane matrix: implications for development. Dev. Biol. 143:303-308.

21. McCaffrey, T. A., D. J. Falcone, and D. V. Baoheng. 1992. Transforming growth factor- $\beta_{1}$ is a heparin-binding protein: identification of putative heparin-binding regions and isolation of heparins with varying affinity for TGF- $\beta_{1}$. J. Cell. Physiol. 152:430-440.

22. Bressler, J. P., G. R. Grotendorst, C. Levitov, and L. M. Hjelmeland. 1985. Chemotaxis of rat brain astrocytes to platelet derived growth factor. Brain Res. 344:249-254.

23. Grotendorst, G. R., Y. Soma, K. Takehara, and M. Charette. 1989. EGF and TGF- $\alpha$ are potent chemoattractants for endothelial cells and EGFlike peptides are present at sites of tissue regeneration. J. Cell. Physiol. 139: 617-623.

24. Higashiyama, S., J. A. Abraham, and M. Klagsbrun. 1993. Heparinbinding-EGF-like growth factor stimulation of smooth muscle cell migration: dependence on interactions with cell-surface heparan sulfate. J. Cell Biol. 122: 933-940.

25. Mawatari, M., K. Okamura, T. Matsuda, R. Hamanaka, H. Mizuguchi, K. Higashio, K. Kohno, and M. Kuwano. 1991. Tumor necrosis factor and epidermal growth factor modulate migration of human microvascular endothelial cells and production of tissue-type plasminogen activator and its inhibitor. Exp. Cell. Res. 192:574-580.

26. Morganti-Kossmann, M. T., M. E. Kossmann, S. E. Brandes, S. M. Mergenhagen, and S. M. Wahl. 1992. Autocrine and paracrine regulation of astrocyte function by transforming growth factor- $\beta$. J. Neuroimmunol. 39:163-174.

27. Turksen, K., Y. Choi, and E. Fuchs. 1991. Transforming growth factor alpha induces collagen degradation and cell migration in differentiating human epidermal raft cultures. Cell Regulation. 2:613-625.

28. Yu, A. C. H., Y. L. Lee, and L. F. Eng. 1993. Astrogliosis in culture: the model and the effect of antisense oligonucleotides on glial fibrillary acidic protein synthesis. J. Neurosci. Res. 34:295-303.

29. Todaro, G. J., and J. E. De Larco. 1976. Transformation by murine and feline sarcoma virus specifically blocks binding of epidermal growth factor to cells. Nature (Lond.). 264:26-31.

30. Marquardt, H., M. W. Hunkapiller, L. E. Hood, D. R. Twardzik, J. E. De Larco, J. R. Stephenson, and G. J. Todaro. 1983. Transforming growth factors produced by retrovirus-transformed rodent fibroblasts and human melanoma cells: amino acid sequence homology with epidermal growth factor. Proc. Natl. Acad. Sci. USA. 80:4684-4688.

31. Marquardt, H., M. W. Hunkapiller, L. E. Hood, and G. J. Todaro. 1984. Rat transforming growth factor type 1: structure and relation to epidermal growth factor. Science (Wash. DC). 223:1079-1082.

32. Higashiyama, S., J. A. Abraham, J. Miller, J. C. Fiddes, and M. Klagsbrun. 1991. A heparin-binding growth factor secreted by macrophage-like cells that is related to EGF. Science (Wash. DC). 51:936-939.

33. Thompson, S. A., S. Higashiyama, K. Wood, N. S. Pollitt, D. Damm, G. McEnroe, B. Garrick, N. Ashton, K. Lau, N. Hancock, M. Klagsbrun, and J. A. Abraham. 1994. Characterization of sequences within heparin-binding EGFlike growth factor that mediate interaction with heparin. J. Biol. Chem. 269: 2541-2549.

34. McCarthy, K. D., and V. deVellis. 1980. Preparation of separate astroglial and oligodendroglia cell cultures from rat cerebral tissue. J. Cell Biol. 85: 890-902.

35. Keller, K. M., P. R. Brauer, and J. M. Keller. 1989. Modulation of cellsurface heparan sulfate structure by growth of cells in the presence of chlorate. Biochemistry. 28:8100-8107.

36. Han, V. K. M., A. Samith, W. Myint, K. Nygard, and S. Baradshaw. 1992. Mitogenic activity of epidermal growth factor on newborn rat astroglia: interaction with insulin-like growth factors. Endocrinology. 131:1134-1142.

37. Westermark, B. 1976. Density dependent proliferation of human glia cells stimulated by epidermal growth factor. Biochem. Biophys. Res. Commun. 69:304-309.

38. Pettmann, B., M. Weibel, M. Sensenbrenner, and G. Labourdette. 1985. Purification of two astroglial growth factors from bovine brain. FEBS Lett. 189:102-108.

39. Huff, K. R., W. Schreier, and L. Ibric. 1990. Proliferation-related re- sponses in rat astrocytes to epidermal growth factor. Int. J. Dev. Neurosci. 8: 255-266.

40. Toru-Delbauffe, D., D. Baghdassarian, D. Both, R. Bernard, P. Rouget, and M. Pierre. 1992. Effects of TGF- $\beta_{1}$ on the proliferation and differentiation of an immortalized astrocyte cell line: relationship with extracellular matrix. Exp. Cell. Res. 202:316-325.

41. Tranque, P. A., R. Calle, F. Naftolin, and R. Robbins. 1992. Involvement of protein kinase $\mathrm{C}$ in the mitogenic effect of insulin-like growth factor-1 on rat astrocytes. Endocrinology. 131:1948-1954.

42. Lindholm, D., E. Castrén, R. Kiefer, F. Zafra, and H. Thoenen. 1992. Transforming growth factor- $b_{1}$ in the rat brain: increase after injury and inhibition of astrocyte proliferation. J. Cell Biol. 117:395-400.

43. Hunter, K. E., M. B. Sporn, and A. M. Davis. 1993. Transforming growth factor-bs inhibit mitogen-stimulated proliferation of astrocytes. Glia. 7: 203-211.

44. Faassen, A. E., J. A. Schrager, D. J. Klein, T. R. Oegema, J. R. Couchman, and J. B. MacCarthy. 1992. A cell-surface chondroitin sulfate proteoglycan, immunologically related to CD44, is involved in type I collagen-mediated melanoma cell motility and invasion. J. Cell Biol. 116:521-531.

45. Kinsella, M. G., and T. N. Wight. 1986. Modulation of sulfated proteoglycan synthesis by bovine aortic endothelial cells during migration. J. Cell Biol. 102:679-687.

46. Wight, T. N., M. G. Kinsella, and E. E. Qwarnström. 1992. The role of proteoglycans in cell adhesion, migration and proliferation. Curr. Opin. Cell Biol. 4:793-801.

47. Giulian, D., and L. B. Lachman. 1985. Interleukin-1 stimulation of astroglial proliferation after brain injury. Science (Wash. DC). 228:497-499.

48. Sivron, T., A. Cohen, D. L. Hirschberg, G. Jeserich, and M. Schwartz. 1991. Soluble factor(s) produced in injured fish optic nerve regulate the postinjury number of oligodendrocytes: possible role of macrophages. Glia. 4:591601

49. Unsicker, K., K. C. Flanders, D. S. Cissel, R. Lafyatis, and M. B. Sporn. 1991. Transforming growth factor-b isoforms in the adult rat central and peripheral nervous system. Neuroscience. 44:613-625.

50. Eitan, S., R. Zisling, A. Cohen, M. Belkin, D. L. Hirschberg, M. Lotan, and M. Schwartz. 1992. Identification of an interleukin-2-like substance as a factor cytotoxic to oligodendrocytes and associated with central nervous system regeneration. Proc. Natl. Acad. Sci. USA. 89:5442-5446.

51. Logan, A., and M. Berry. 1993. Transforming growth factor- $b_{1}$ and basic fibroblast growth factor in the injured CNS. Trends Pharmacol. Sci. 14:337343.

52. Krane, J. F., A. B. Gottlieb, D. M. Carter, and J. G. Krueger. 1992. The insulin-like growth factor-I receptor is overexpressed in psoriatic epidermis, but is differentially regulated from the epidermal growth factor receptor. $J$. Exp. Med. 175:1081-1090.

53. Spencer, E. M., G. Skover, and T. K. Hunt. 1988. Somatomedins: do they play a pivotal role in wound healing? In Growth factors and other aspects of wound healing: biological and clinical applications. A. Barbur, E. Pines, M. Caldwell, and T. K. Hunt, editors, Alan R Liss, Inc. 103-116.

54. Labourdette, G., T. Janet, P. Laeng, F. Perraud, D. Lawrence, and B. Pettmann. 1990. Transforming growth factor- $b_{1}$ modulates the effects of basic fibroblasts growth factor on growth and phenotypic expression of rat astroblasts in vitro. J. Cell. Physiol. 144:473-484.

55. McCormack, S. A., M. J., Viar, and L. R. Johnson. 1992. Migration of IEC-6 cells: a model for mucosal healing. Am. J. Physiol. 263:G426-G435.

56. Saad, B., D. B. Constam, R. Ortmann, M. Moos, A. Fontana, and M. Schachner. 1991. Astrocyte-derived TGF-2 and NGF differentially regulate neural recognition molecule expression by cultured astrocytes. J. Cell. Biol. 115: 473-484.

57. Heino, J., R. A. Ignotz, M. E. Hemler, C. Crouse, and J. Massagué. 1989. Regulation of cell adhesion receptors by transforming growth factor-b. $J$. Biol. Chem. 264:380-388.

58. Baghdassarian, D., D. Toru-Delbauffe, J. M. Gavaret, and M. Pierre. 1993. Effects of transforming growth factor- $\beta_{1}$ on the extracellular matrix and cytoskeleton of cultured astrocytes. Glia. 7:193-202.

59. Martin, G. R., R. Timple, and K. Kühn. 1988. Basement membrane proteins: molecular structure and function. Adv. Protein. Chem. 39:1-50.

60. Erickson, H. P., and V. A. Lightner. 1988. Haxabrachion protein tenascin, cytotactin, brachionectin in connective tissues, embryonic brain, and tumors. Adv. Cell. Biol. 2:55-90.

61. Lawler, J., and R. O. Hynes. 1986. The structure of human thrombospondin, an adhesive glycoprotein with multiple calcium-binding sites and homologies with several different proteins. J. Cell Biol. 103:1635-1648.

62. Roberts, C. J., T. M. Birkenmeier, J. J. McQuillan, S. K. Akiyama, S. S. Yamada, W. T. Chen, K. M. Yamada, and J. A. McDonald. 1988. Transforming growth factor-b stimulates the expression of fibronectin and of both subunits of the human fibronectin receptor by cultured human lung fibroblasts. J. Biol. Chem. 263:4586-4592.

63. Ignotz, R. A., J. Heino, and J. Massagué. 1989. Regulation of cell adhesion receptors by transforming growth factor-b. J. Biol. Chem. 264:389-392.

64. Bassols, A., and J. Massagué. 1988. Transforming growth factor-b regulates the expression and structure of extracellular matrix chondroitin/dermatan 
sulfate proteoglycans. J. Biol. Chem. 263:3039-3045.

65. Hiraki, Y., H. Inoue, R. Hirai, Y. Kato, and F. Suzuki. 1988. Effect of transforming growth factor-b on cell proliferation and glycosaminoglycan synthesis by rabbit growth-plate chondrocytes in culture. Biochim. Biophys. Acta. 969:91-99.

66. Madri, J. A., B. M. Pratt, and A. M. Tuker. 1988. Phenotypic modulation of endothelial cells by transforming growth factor-b depends upon the composition and organization of the extracellular matrix. J. Cell Biol. 106:13751384.

67. Morales, T., and A. B. Roberts. 1988. Transforming growth factor-b regulates the metabolism of proteoglycans in bovine cartilage organ cultures. $J$. Biol. Chem. 263:12828-12831.

68. Constam, D. B., J. Philipp, U. V. Malipiero, P. Ten Dijke, M. Schachner, and A. Fontana. 1992. Differential expression of transforming growth factor- $\mathrm{b}_{1}, \mathrm{~b}_{2}$ and $\mathrm{b}_{3}$ by glioblastoma cells, astrocytes, and microglia. $J$. Immunol. 148:1404-1410.

69. García-Estrada J., L. M. García-Segura, and I. Torres-Alemán. 1992. Expression of insulin-like growth factor-1 by astrocytes in response to injury. Brain Res. 592:343-347.

70. Chernausek, S. D. 1993. Insulin-like growth factor (IGF-1) production by astroglial cells: regulation and importance for epidermal growth factor-induced cell replication. J. Neurosci. Res. 34:189-197.

71. Emoto, N., A. M. González, P. A. Walicke, E. Wada, D. M. Simmons, S. Shimasaki, and A. Baird. 1989. Basic fibroblasts growth factor (FGF) in the central nervous system: identification of specific loci of basic FGF expression in the rat brain. Growth Factors. 2:21-29.

72. Assoian, R. K., A. Komoriya, C. A. Meyers, D. M. Miller, and M. B. Sporn. 1983. Transforming growth factor-b in human platelets. J. Biol. Chem. 258:7155-7160.

73. Rom, W. N., P. Basset, G. A. Fells, T. Nukiwa, B. C. Trapnell, and R. G. Crysal. 1988. Alveolar macrophages release an insulin-like growth factor-I type molecule. J. Clin. Invest. 82:1685-1693.

74. Nagaoka, I., B. C. Trapnell, and R. G. Crystal. 1990. Regulation of insulin-like growth factor-I gene expression in the human macrophage-like cell line U937. J. Clin. Invest. 85:448-455.

75. Besner, G., S. Higashiyan, and M. Klagsburn. 1990. Isolation and characterization of a macrophage-derived heparin-binding growth factor. Cell Regen. 1:811-819.

76. Recio-Pinto, E., and D. N. Ishii. 1984. Effects of insulin, insulin-like growth factor-II and nerve growth factor on neurite outgrowth in cultured human neuroblastoma cells. Brain Res. 302:323-334.

77. Recio-Pinto, E., and D. N. Ishii. 1988. Insulin and related growth factors: effects on the nervous system and mechanism for neurite growth and regeneration. Neurochem. Int. 12:397-414.

78. Hanson, H., L. B. Dahlin, N. Danielsen, L. Fryklund, M. K. Nachemson, P. Polleryd, B. Rozell, A. Skottner, S. Stemme, and G. Lundborg. 1986. Evidence indicating trophic importance of IGF-1 in regenerating peripheral nerves. Acta. Physiol. Scand. 126:609-614.

79. Kanje, M., J. Askottner, G. Sjoberg, and G. Lundborg. 1989. Insulinlike growth factor-1 (IGF-1) stimulates regeneration of the rat sciatic nerve. Brain Res. 486:396-398.

80. Gluckman, P. D., N. D. Klempt, J. Guan, E. C. Mallard, E. Sirimanne, M. Dragunow, M. Llempt, K. Singh, C. E. Williams, and K. Nikolos. 1992. A role for IGF-1 in the rescue of CNS neurons following hypoxic-ischemic injury. Biochem. Biophys. Res. Commun. 182:593-599.

81. Saksela, O., D. Moscattelli, A. Sommer, and D. B. Rifkin. 1988. Endothelial cell-derived heparan sulfate binds basic fibroblast growth factor and protects it from proteolytic degradation. J. Cell Biol. 197:743-751.

82. Sievers, J., B. Havsmann, K. Unsicker, and M. Berry. 1987. Fibroblast growth factors promote the survival of adult rat retinal ganglion cells after transection of the optic nerve. Neurosci. Lett. 76:157-162.

83. Anderson, K. J., D. Dam, S. Lee, and C. W. Cotman. 1988. Basic fibroblast growth factor prevents death of lesioned cholinergic neurons in vivo. $\mathrm{Na}$ ture (Lond.). 332:360-361.

84. Otto, D., M. Frotscher, and K. Unsicker. 1989. Basic fibroblast growth factor and nerve growth factor administered in gel foam rescue medial septal neurons after fimbria fornix transection. J. Neurosci. Res. 22:83-91.

85. Sweetnam, P. M., H. R. Sanon, L. A. White, B. J. Brass, M. Jaye, and S. R. Whittemore. 1991. Differential effects of acidic and basic fibroblas growth factors on spinal cord cholinergic, GABAergic, and glutamatergic neurons. J. Neurochem. 57:237-249.

86. Gospodarowicz, D., and J. Cheng. 1986. Heparin protects basic and acidic FGF from inactivation. J. Cell. Physiol. 128:475-484.

87. Moscatelli, D. 1987. High- and low-affinity-binding sites for basic fibroblast growth factor on cultured cells: absence of a role for low-affinity binding in the stimulation of plasminogen activator production by bovine capillary endothelial cells. J. Cell. Physiol. 131:123-130. 